\title{
Voice More and Stay Longer: How Ethical Leaders Influence Employee Voice and Exit Intentions
}

\author{
Long W. Lam \\ Raymond Loi \\ Ka Wai Chan \\ University of Macau
}

\author{
Yan Liu \\ Wuhan University
}

\begin{abstract}
Given the importance of voice in ethical leadership theory, we analyze the relationship of ethical leadership to employee voice and the relationship of voice to exit intentions. Building on the theory of work engagement, we further hypothesize that cognitive engagement mediates these proposed relationships. To test these propositions, we conduct a field study to relate ethical leadership of supervisors, measured at time 1, to employees' cognitive job engagement, measured at time 2 . The analyses show that the relationship between these variables can account for supervisory ethical leadership's association with employee voice and exit intentions. In a supplementary study using a different sample, we find that supervisory ethical leadership is related to exit intentions through voice. We discuss how these findings contribute to the literature on ethical leadership, employee voice, and exit.
\end{abstract}

KEY WORDS: Ethical leadership, voice, exit, work engagement, motivation, China

\section{INTRODUCTION}

$\mathrm{W}$

HILE MASS MEDIA has often focused on the ethical behaviors of corporate leaders (Huang, 2010), a growing number of researchers are also interested in this particular leadership because of its connection with outcomes such as employees' task performance and citizenship behavior (e.g., Piccolo, Greenbaum, Hartog, \& Folger, 2010) and reduction of unethical behaviors (Mayer, Aquino, Greenbaum, \& Kuenzi 2012; Taylor \& Pattie, 2014). Here, ethical leadership refers to "the demonstration of normatively appropriate conduct through personal actions and interpersonal relationships, and the promotion of such conduct to followers through two-way communication, reinforcement, and decision-making" (Brown, Treviño, \& Harrison 2005: 120). One crucial premise of ethical leadership theory is that ethical leaders "provide followers with voice" (Brown et al., 2005: 120), with voice defined as the "discretionary verbal communication of ideas, suggestions, 
or opinions with the intent to improve organizational or unit functioning" (Morrison, Wheeler-Smith, \& Kamdar, 2011: 183). Because ethical leaders emphasize two-way communication, voice should emerge because ethical leaders are more willing to listen to employees. Ethical leaders also emphasize doing and saying the right thing, thus motivating employees to emulate their leaders by voicing opinions more frequently (Walumbwa \& Schaubroeck, 2009). Bashshur and Oc's (2015) meta-analyses show that when employees voice, teams become more creative and make better decisions, and organizations are able to adapt and change more quickly. Thus, voice is an important outcome for both organizations and our understanding of ethical leadership.

Therefore, our study's objectives are twofold. First, given the important role of voice in ethical leadership theory (Brown et al., 2005) and implications for organizational functioning (Van Dyne \& LePine, 1998), we intend to re-examine whether employee voice can be attributed to ethical leadership of supervisors in two samples of employees in China (e.g., Avey, Wernsing, \& Palanski, 2012; Lam, Xu, \& Lau, 2012; Walumbwa, Morrison, \& Christensen, 2012; Walumbwa \& Schaubroeck, 2009), a cultural context in which the value of power distance dominates and speaking up is discouraged (Brockner et al., 2001). Informed by Kahn's (1990) theory of work engagement, we also examine whether cognitive engagement accounts for the relationship between ethical leadership and voice. Second, we aim to extend understanding of the relationship between ethical leadership and voice by incorporating the role of employee exit intentions. Specifically, if ethical leadership promotes voice, does it also discourage exit intentions (i.e., employees' voluntary intentions to leave the organization) (Lee \& Mitchell, 1994)?

In fulfilling these research objectives, our study makes several contributions. First, prior research has demonstrated that ethical leaders influence followers through social learning and social exchange mechanisms (e.g., Mayer et al., 2012; Walumbwa et al., 2011). However, in addition to demonstrating normatively appropriate conduct and establishment of interpersonal relationships, ethical leadership theory posits that ethical leaders promote conduct through reinforcement, two-way communication, and decision-making. As such, motivation may be another important mechanism for ethical leaders to foster desirable behaviors among followers. Shamir, House, and Arthur (1993) argue that value-driven leaders are able to shape followers' self-concept and, thus, their motivation, whereas Kahn's (1990) theory of work engagement posits that a connection between one's self and role is an important motivational state for effective work performance. By examining the mediation mechanism of cognitive engagement, an important motivational state of mind at work according to Kahn's theory, we may gain more understanding of the processes by which the relationship between supervisors' ethical leadership and its outcomes (i.e., voice and exit intentions) occurs.

Second, one reason organizations need to consider ethical leadership, according to Thomas, Schermerhorn, and Dienhart (2004), is to reduce business costs associated with lost employee morale and turnover (see also Mayer et al., 2012). Employee turnover is particularly troubling for organizations because of the 
lengthy process of re-hiring and re-training employees. Brown and Treviño (2006) also propose that ethical leadership, owing to leader fairness, trustworthiness, and honesty, can enhance employees' motivation and commitment, which can be expected to lessen turnover intention. Thus, we consider the linkage between supervisory ethical leadership and employee exit intentions to be an important one in the literature. Prior research on employee dissatisfaction suggests that voice and exit are inter-related, in that employees are less likely to quit organizations if they are allowed to air their concerns through voice (e.g., Hirschman, 1970; Rusbult, Farrell, Rogers, \& Mainous, 1988; Withey \& Cooper, 1989). By extending the relationship between supervisory ethical leadership and voice to exit intentions, we can shed better light on how ethical leaders can reduce employees' turnover intentions.

Third, despite continuing research on the positive outcomes associated with ethical leadership (e.g., Mayer, Kuenzi, Greenbaum, Bardes, \& Salvador, 2009; Neubert, Carlson, Kacmar, Roberts, \& Chonko, 2009; Walumbwa et al., 2011), evidence of the effect of ethical leadership on negative forms of behavior is less conclusive (e.g., Detert, Treviño, Burris, \& Andiappan, 2007). By examining employee voice and exit together, this study addresses how organizations can use ethical leadership of supervisors to increase positive outcomes and reduce negative reactions of employees simultaneously.

\section{DEVELOPMENT OF HYPOTHESES}

\section{What is Ethical Leadership?}

Brown (2007) identifies ethical leaders as those who help steer an organization in the right direction by pursuing activities society considers normatively appropriate and morally correct (Brown et al., 2005; Mendonca \& Kanungo, 2007). Others describe ethical leaders as honest, fair, and caring individuals who hold high moral standards (Brown \& Treviño, 2006; Brown et al., 2005). Because ethical leaders are moral individuals, followers find them credible and legitimate role models to emulate (Brown et al., 2005). Thus, through social learning, employees can develop positive work attitudes and normatively appropriate forms of behavior under ethical leaders (Bandura, 1986). For example, an Ethics Research Centre (2011) study found that employees were more likely to adhere to higher standards of performance when they witnessed leaders relying on ethics in behaving and decision-making. In addition to being moral individuals, ethical leaders conduct their daily management in a moral manner. Ethical leaders expect their followers to have high moral standards and are likely to use transactional methods, such as rewards and punishment, to ensure that followers meet their expectations (Brown et al., 2005). Previous research has argued that, in addition to acting as role models, ethical leaders create a work climate that fosters more interpersonal relational exchanges, resulting in greater satisfaction with supervisors, more willingness to report problems, and stronger affective commitment (e.g., Brown \& Treviño, 2006; Neubert et al., 2009; Walumbwa et al., 2011). In addition to ethical leadership's effects on positive outcomes (e.g., task performance and organizational citizenship behaviors), Treviño and Brown's (2014) 
review further reveals whether ethical leadership can be associated with reduction of negative outcomes such as counterproductive behavior, deviance, and unethical behavior. While Detert et al. (2007) did not find support for a negative relationship between ethical leadership and counterproductive behavior, Mayer et al.'s (2009, 2012) studies reported less deviance and unethical behavior as a result of executive and supervisory ethical leadership.

According to Brown et al. (2005), employee voice is likely to emerge under ethical leadership because this type of leadership emphasizes two-way communication and ethical leaders are more willing to listen to employees. Treviño, Brown, and Hartman (2003: 18) further characterize ethical leaders as individuals to whom subordinates "can bring up present problems" and even "tough issues." Because voice is a crucial part of ethical leadership theory, it is important to understand how ethical leadership can connect with employees' decisions to voice in organizations. Shamir et al. (1993) argue that value-driven leaders attempt to alter the value and aspiration of followers from self- to collective interests. In referring to followers' self-concept, the authors further argue that followers of such leaders develop strong attachments to leaders' mission and become more motivationally aroused. Ethical leaders fit with this description of value-driven leaders because they are "fair and principled decision-makers who care about people and the broader society" and "make ethics an explicit part of their leadership agenda" (Brown \& Treviño, 2006: 597). Thus, we consider whether motivation and engagement are important means for ethical leaders to influence employees' outcomes such as voice (Walumbwa \& Schaubroeck, 2009). In the following sections, we use Kahn's (1990) theory of work engagement as a basis to hypothesize how supervisory ethical leadership is related to employee voice through cognitive engagement and how it can reduce employee exit intentions by encouraging voice.

\section{Supervisory Ethical Leadership, Cognitive Engagement, and Voice}

To understand why individuals focus their energies in the performance of work roles, Kahn (1990) developed a theory of motivation known as work engagement. The work engagement literature suggests that people can be either engaged or disengaged in work. Engaged people are psychologically present (Rothbard, 2001) and invest more energy into role performance (Rich, Lepine, \& Crawford 2010), while disengaged employees are usually more detached, apathetic, and passive and thus withhold their best efforts (Bolton et al., 2012; Burris, Detert, \& Chiaburu, 2008; Hochschild, 1983). According to Kahn (1990: 700), work engagement is "the simultaneous employment and expression of a person's 'preferred self' in task behaviors that promote connections to work and to others." When people "harness their full selves in active, work role performance," they become "cognitively vigilant, focused and attentive" (Rich, Lepine, \& Crawford, 2010: 619). Therefore, in addition to effective task performance, researchers have considered work engagement a particular motivational state in fulfilling a demanding job (e.g., Crawford, Lepine, \& Rich, 2010; Schaufeli \& Bakker, 2004) and performing a complex work role (Rothbard, 2001). Rich et al (2010) show that work 
engagement is a distinct motivational construct that accounts for differences in employees' task performance and organizational citizenship behavior (e.g., voicing ideas to improve organizational functioning), in addition to the effects of job involvement and intrinsic motivation.

Kahn (1990: 700) contends that an individual's "self and role exist in some dynamic, negotiable relation" and that given the right psychological conditions, the person becomes fully engaged and "drives personal energies into role behaviors (self-employment) and displays the self within the role (self-expression)." On the basis of his qualitative studies, Kahn proposed three psychological conditions under which work engagement is likely to take place: psychological meaningfulness, safety, and availability. According to Kahn, cognitively engaged individuals harness their minds to fulfill their role requirements by investing their cognitive or attention resources (Kanfer \& Ackerman, 1989). Unlike physical and emotional engagement, which involves investing "hand" and "heart" in fulfilling jobs (Rich et al., 2010), cognitively engaged individuals put their "head" into their work (i.e., are focused, vigilant, and mindful), which is the most desirable condition for employees to identify work problems and to ponder suggestions for improvement (Weick \& Roberts, 1993).

Kahn (1990) characterizes psychological meaningfulness as the worthiness and value of work; psychological meaningfulness fosters work engagement because it represents a form of return when an individual invests his or her preferred self in role performance (Kahn 1990; May, Gilson, \& Harter, 2004). By emphasizing moral values and normatively appropriate conduct (e.g., honesty), ethical leaders infuse their employees with ethics and a sense of value in their work (Brown et al., 2005; Piccolo et al., 2010). Ethical leadership theorists have suggested that when employees are asked to behave according to what society deems morally correct, they are more likely to feel a sense of fulfillment when serving others, which makes their jobs more meaningful (Brown et al., 2005; Mendonca \& Kanungo, 2007). As such, employees may be more engaged at work because of supervisory ethical leadership. Consistent with our expectations, Piccolo et al. (2010) show that working students view their jobs as more significant under ethical leaders, and Lin (2010) finds that employees show greater engagement when working for organizations that are good corporate citizens.

Kahn (1990: 708) describes psychological safety as the experience of "feeling able to show and employ one's self without fear of negative consequences to self-image, status, or career." Compared with psychologically safe situations in which employees are more focused, in perceived unsafe work environments, employees are less able to completely focus on performing their roles if they need to spend cognitive resources on protecting their personal interests. Mayer and Gavin (2005) show that subordinates are less focused on their tasks (i.e., low cognitive engagement) when they need to monitor supervisors' actions to reduce their own vulnerability. Conversely, ethical leaders are honest, caring, trustworthy, and fair (Brown \& Treviño, 2006; Treviño, Brown, \& Hartman, 2003), and thus, employees feel less vulnerable and are able to focus on work. Subordinates working under leaders who treat them with dignity and respect are also less concerned that their supervisors will undermine 
their work and ideas. Therefore, we reason that employees working under ethical leaders are more likely to be cognitively engaged. Walumbwa et al.'s (2011) study provides supporting evidence for the hypothesis that employees are better able to focus on their task performance under ethical leaders.

Finally, enacting one's work role can deplete cognitive resources when it requires multiple tasks to be performed concurrently or the task itself requires considerable information processing to comprehend (May et al., 2004). Thus, another way for ethical leaders to foster greater cognitive engagement among followers is to improve their psychological availability, defined as individuals' readiness and willingness to devote additional energies to performing a required role (Kahn, 1990). We expect that individuals will be more ready and willing to do so if they believe that they are capable of fulfilling the role requirement (i.e., self-efficacy) and their efforts will result in desirable outcomes (i.e., valence). Ethical leaders make themselves available to followers through two-way communication. Because followers are better able to receive help and guidance from their ethical leaders, their self-efficacy to perform their work roles may also increase. Moreover, by infusing moral purposes into work, ethical leaders enhance the intrinsic valence of followers' efforts by increasing the perceived moral correctness of their behaviors, which, according to Shamir et al. (1993), can be particularly motivating. For these reasons, we expect employees to become more ready and willing to devote cognitive resources under supervisory ethical leadership (i.e., be more cognitively engaged).

When engaged employees harness their selves within their work roles, they become more authentic by displaying real feelings and abilities (i.e., self-expression) and voicing their thoughts more often (Kahn, 1990). Specifically, we expect that cognitive engagement is related to employee voice for three reasons. First, because cognitively engaged employees invest more fully in their work roles, their connection with work will also increase, such that they take additional pride in what they are doing. Such employees are likely to take initiative in pursuing proactive behaviors, such as voice, to benefit organizations (Den Hartog \& Belschak, 2012). Second, when employees are cognitively engaged in the performance of work roles, they are more focused, vigilant, and attentive (Rich et al., 2010). As such, their active minds can aid them in spotting mistakes and coming up with thoughtful suggestions. In their study of flight operators in aircraft carriers, Weick and Roberts (1993) reported that operational errors decreased when employees were more attentive and mindful, collectively. In another study of work engagement, Kahn (1992) noted that when project managers focused on the assigned work, they offered more suggestions and constructive criticisms in organizations. Third, in addition to focus and vigilance, cognitively engaged employees may become more persistent (May et al., 2004). When encountering difficulties at work, they are likely to propose suggestions to resolve the problems (i.e., more voice).

In summary, we argue that employee voice is more common under supervisors who are ethical leaders because their suggestions are likely to be taken seriously (Walumbwa et al., 2012). We expect cognitive engagement to be a crucial mediator, 
as employees are more engaged when working under ethical leaders; engagement also allows them to focus on work and develop ideas for improvement. Thus:

H1. Cognitive engagement mediates the positive relationship between supervisory ethical leadership and employee voice.

\section{Supervisory Ethical Leadership, Voice, and Exit Intentions}

We further expect that employees are less likely to exit when they have the opportunity to voice their ideas. Research suggests that when employees are able to express their opinions in organizations, they tend to view themselves as valued members, as their inputs are part of the decision-making process (Lind \& Tyler, 1988; Morrison \& Milliken, 2000). When employees believe that their organizations value them, they are more likely to reciprocate by offering the organization greater commitment (Eisenberger, Armeli, Rexwinkel, Lynch, \& Rhoades, 2001; Loi, Ngo, \& Foley, 2006). Thus, employees' voice can reduce intentions to exit. Withey and Cooper (1989) show that employees are less likely to exit when they realize that their voice can bring changes to the organization.

Voice also enhances employees' feelings of control over their immediate environment, so they believe that they can shape what will happen in their workplace (Tangirala \& Ramanujam 2008). When employees believe that they have little input into their organizations' future, researchers have proposed that such employees may enter a state of collective apathy and withdrawal (Morrison \& Milliken, 2000) so that their intentions to leave also increase (Milliken, Morrison, \& Hewlin, 2003). We argue that the opposite effect will occur when employees are encouraged to voice their ideas. Through voice, employees believe that organizations take their opinions seriously and that they can influence the organization. When "individuals feel that they can influence ... through the available voice mechanism ... they are more likely to use voice and less likely to exit the firm" (Boroff \& Lewin, 1997: 53). Consistent with our expectations, Spencer (1986) reports that voice mechanisms are negatively related to turnover among nurses, and Olson-Buchanan and Boswell (2002) show that the proper use of voice methods reduces job search activities and intentions to quit among university employees. These arguments lead to the following hypothesis:

\section{H2. Employee voice is negatively related to employee exit intentions.}

Voice makes employees feel respected and gives them a sense of control, reducing their exit intentions. Thus, the increase in employee voice that results from cognitive engagement and derives from ethical leadership will likely contribute to the reduction of exit intentions. Specifically, we expect followers of supervisory ethical leaders to have lower exit intentions because of ethical leaders' characteristics (e.g., fairness, trustworthiness) and values (e.g., concern about people and the broader society, achievement of common, rather than selfish, goals) (Brown \& Treviño, 2006; Treviño, et al., 2003). Because employees tend to believe that leaders and organizations share the same characteristics (Eisenberger \& Stinglhamber, 2011), they are likely to believe that organizations embrace the same values endorsed by 
ethical leaders and are likely to develop stronger organizational attachments and lower exit intentions. Studies conducted by Treviño, Butterfield, and McCabe (1998) and Loi, Lam, Ngo and Cheong (2015) reveal employees to be more committed to organizations of strong ethical culture, climate, and leadership, whereas Palanski, Avey, and Jiraporn (2014) show that employee turnover intentions are negatively related to ethical leadership. In addition, by promoting cognitive engagement, ethical leaders enable followers to use voice and to share suggestions of how to improve organizational functioning. When employees believe that they have an influence on organizations, their intentions to stay with the organization are likely to increase. Prior research has shown that employees choose to stay longer in the workplace to observe the outcomes of their ideas (Arkes \& Blumer, 1985; Rusbult et al., 1988). Thus, we posit a linkage between supervisory ethical leadership and employee exit intentions:

H3. Supervisory ethical leadership is indirectly related to employee exit intentions through the mediating influence of cognitive engagement and, in turn, employee voice.

\section{METHODS}

\section{Sample and Procedures}

To test our hypotheses, we collected two-phase survey data from two garment manufacturing companies located in Macau and Zhuhai. Both cities are located in the southern part of mainland China. The same owner manages both manufacturing companies, so there are no notable differences between them in terms of ownership and production operations, which justified the merging of our data into a single sample.

We first distributed a questionnaire survey to all employees of the two companies (i.e., 196 employees at the Macau site and 283 employees at the Zhuhai site). The respondents provided ratings on items regarding ethical leadership of their supervisors, employee silence, and intention to quit. With assistance of the human resource departments of the two companies, we obtained the lists of employees and assigned a code for each employee for matching purposes. To ensure confidentiality, we did not disclose these codes to the companies; the cover page of the questionnaire showed only the respondent's code. The respondents were also asked to return the completed questionnaires directly to the researchers. This process ensured anonymity of the responses obtained. We collected the returned questionnaires on the same day as distribution. In total, we received 381 completed and usable surveys, 149 from Macau and 232 from Zhuhai, yielding response rates of $76 \%$ and $82 \%$, respectively.

Five months later, we conducted the second questionnaire survey with the 381 employees who have responded to the previous survey. Due to voluntary turnover and staff absence, we distributed 140 questionnaires at the Macau site and 177 at the Zhuhai site. Respondents provided ratings on items regarding cognitive engagement, voice, and intention to quit, along with other control variables. In total, we received 306 completed and usable surveys, 137 from Macau and 169 from Zhuhai, yielding response rates of $98 \%$ and $95 \%$, respectively. 
Our final sample contains $76.1 \%$ women, and $46.6 \%$ are aged $31-40$ years. Respondents' average organizational tenure is 5.33 years. Among them, $17 \%$ received education at the primary-school level, $61 \%$ had a junior high school education, $18 \%$ had a senior high school education, and $4 \%$ received a university education or above. Approximately $26 \%$ are paid monthly, and the rest are paid either on a daily $(26 \%)$ or piecework (48\%) basis. There is no significant difference between the final sample $(n=306)$ and the target sample $(n=381)$ in terms of demographics.

\section{Measures}

A 6-point Likert-type scale ( 1 = "strongly disagree"; 6 = "strongly agree") was used to rate all the items. The questionnaires were written in Chinese, so we used back translation (Brislin, 1970) in which the original English measurement scales were translated into Chinese and then translated back into English.

Supervisory ethical leadership (T1). We use the 10-item ethical leadership scale developed by Brown et al. (2005). One sample question is "My supervisor conducts his/her personal life in an ethical manner". The coefficient alpha is .87 .

Cognitive engagement (T2). To measure this variable, we use the cognitive dimension of the engagement scale developed by May et al. (2004). This scale has four items, and sample questions are "I am rarely distracted when performing my job" and "Performing my job is so absorbing that I forget about everything else". The reliability coefficient of this scale is .69.

Voice (T2). We measure this construct with six items modified from the measurement scale of Van Dyne and LePine (1998). Sample items are "I speak up and encourage others in this department to get involved in issues that affect the group," and "I speak up with ideas for new projects or changes in procedures". Cronbach's alpha for this scale is .82 .

Exit intentions (T2). We use Rosin and Korabik's (1991) 4-item scale to measure exit intentions. An example of this scale is "At this time, I would quit my job if it were feasible". This scale has a Cronbach's alpha of .83 .

Control variables. We control for several variables in our model. First, because we collected data in different sites, we add a dummy variable $(1=$ Zhuhai; $0=$ Macau $)$ in analyses involving voice and exit intentions. Second, in analyzing exit intentions (T2), we control for T1 exit intentions and employability measured at T2. By controlling for exit intentions measured at $\mathrm{T} 1$, we can rule out the impact of relatively stable factors (e.g., human resource policy) on exit intentions measured at T2. Cronbach's alpha of T1 exit intentions is .87. Employability describes individuals' proactive adaptability in identifying and realizing career opportunities; a highly employable individual may be more apt to leave an organization to gain better employment opportunities (Fugate, Kinicki, \& Ashforth, 2004). Employment opportunities are particularly plentiful in Macau and Zhuhai, the sites of our data collection, due to the combination of a booming economy and a labor shortage. Thus, we expect that employees of high employability will actively consider and pursue career opportunities in this context (Fugate et al., 2004). To determine whether employee exit is due to ethical leadership, we need to account for employability in this study. We therefore adapt De Cuyper, Notelaers, and De Witte's (2009) 4-item scale to measure employability. Cronbach's alpha for this scale is .85. 
In analyzing voice (T2), we also control for employee silence (measured at T1). Employee silence refers to the intentional withholding of information from others (Milliken et al., 2003). Prior research on voice suggests that fear and retaliation explain why individuals are afraid to use voice (Premeaux \& Bedeian, 2003). When employees are concerned about the consequences of speaking out, they are likely to withhold their thoughts (i.e., be silent). By controlling for employees' silence at T1, we can determine whether employees' voice at T2 is due to ethical leadership or other factors inhibiting their intentions to use voice (Milliken et al., 2003; Premeaux \& Bedeian, 2003). We measure employee silence using the modified 5-item scale developed by Tangirala and Ramanujam (2008). Cronbach's alpha for this scale is .74. Appendix I shows all the scale items of the measured variables.

\section{Data Analyses}

Our conceptual model and hypotheses involve tests of mediation (Frazier, Tix, \& Barron, 2004; Kenny, Kashy, \& Bolger, 1998; MacKinnon, Lockwood, \& Williams, 2004; Shrout \& Bolger, 2002). In analyzing these mediations, we use structural equation modeling (based on LISREL 8.8) because it allows us to analyze whether ethical leadership is negatively related to employee exit intentions through cognitive engagement and voice.

In structural equation modeling (SEM) analysis, the first step is to determine the overall fitness of the measurement and the proposed causal model. We estimate the fit of our measurement model using confirmatory factor analyses (CFA) in terms of comparative (CFI) and incremental (IFI) fit indices and root mean square error of approximation (RMSEA). The model is regarded as having achieved a reasonable fit if the CFI and IFI are above 0.90 (Bentler \& Bonett, 1980; Bryne, 1989; Hu \& Bentler, 1998) and the RMSEA is below 0.08 (Brown \& Cudeck, 1993). We then examine two alternative SEM structural models to test our mediation hypotheses (Schneider, Ehrhart, Mayer, Saltz, \& Niles-Jolly, 2005). First, we estimate an SEM model (Model 1) according to our hypothesized model (i.e., Figure 1), which includes paths from supervisory ethical leadership to cognitive engagement, from cognitive engagement to voice, and from voice to exit intentions. In other words, in this model, supervisory ethical leadership is related to exit intentions only indirectly through cognitive engagement and voice. Second, we estimate an alternative SEM model (Model 2) to which we add one direct path from supervisory ethical

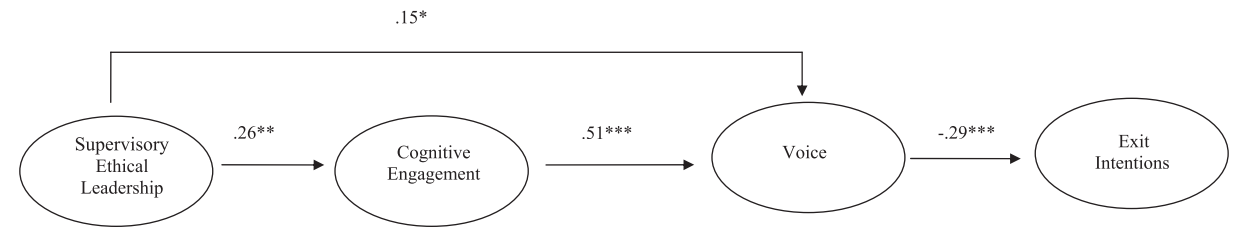

Figure 1: LISREL Results for the Study 1 Causal Model.

Note. Standardized path coefficients are reported. ** $p<.01 ; * * * p<.001$.

To simplify the diagram, control variables are not shown. The path coefficients are dummy (T1) $\rightarrow$ voice $(\mathrm{T} 2)(\beta=.60$ $p<.1)$; silence (T1) $\rightarrow$ voice (T2) $(\beta=-.05$, n.s.); dummy (T1) $\rightarrow$ exit intentions (T2) $(\beta=.71 p<.1)$; exit intentions (T1) $\rightarrow$ exit intentions (T2) $(\beta=.43 p<.001)$; employability (T2) $\rightarrow$ exit intentions (T2) $(\beta=.34, p<.001)$. 
leadership to employee voice and one direct path from ethical leadership to employee exit intentions. To determine which model has the best fit, we examine the significance of the chi-square change.

In addition to the significance of the paths, we evaluate the indirect or mediating effect of $\mathrm{X}$ on $\mathrm{Y}$ through $\mathrm{M}$, by determining the statistical significance of the product term " $\mathrm{a} \times \mathrm{b}$ " in which " $\mathrm{a}$ " represents the path from $\mathrm{X}$ to $\mathrm{M}$ and " $\mathrm{b}$ " represents the path from $\mathrm{M}$ to $\mathrm{Y}$. For example, in testing for $\mathrm{H} 1, \mathrm{X}$ is supervisory ethical leadership, $\mathrm{M}$ is cognitive engagement, and $\mathrm{Y}$ is voice. Consistent with other studies on ethical leadership and employees' proactive activities to voice their suggestions (e.g., Gong, Cheung, Wang, \& Huang, 2012; Walumbwa et al., 2011; Walumbwa \& Schaubroeck, 2009), we use Sobel tests to evaluate the significance of the product term $a \times b$.

\section{RESULTS}

Table 1 shows the means, standard deviations, and correlations among all the variables. Consistent with our hypotheses, supervisory ethical leadership is significantly correlated with cognitive engagement $(\mathrm{r}=.21, \mathrm{p}<.01)$, voice $(\mathrm{r}=.26, \mathrm{p}<.001)$, and exit intentions $(\mathrm{r}=-.23, \mathrm{p}<.001)$, and cognitive engagement is also significantly correlated with voice $(\mathrm{r}=.45, \mathrm{p}<.001)$ and exit intentions $(\mathrm{r}=-.25, \mathrm{p}<.001)$.

For the SEM, we need to demonstrate the fit of the measurement model before analyzing the causal model. To do so, we compare a seven-factor model (supervisory ethical leadership, cognitive engagement, voice, exit intentions, silence, lag exit intentions, and employability) with one-factor model and two other alternative models. One alternative model includes variables measured at T1 as one factor and $\mathrm{T} 2$ as another factor. In the other alternative model, the first factor has independent and control variables, the second factor has the mediators, and the third factor has the outcome according to the study's conceptual model (i.e., supervisory ethical leadership $\rightarrow$ cognitive engagement $\rightarrow$ voice $\rightarrow$ exit intentions). As Table 2 shows, the CFA results indicate that the constructs in this study are distinct. The seven-factor model offers the best fit $\left(\chi^{2}=987.41\right.$, degrees of freedom [d.f.] $=609$; CFI $=.95$;

Table 1: Means, Standard Deviations, Reliabilities, and Inter-Correlations of Study 1 Variables

\begin{tabular}{|c|c|c|c|c|c|c|c|c|c|c|}
\hline & Variables & Mean & SD & 1 & 2 & 3 & 4 & 5 & 6 & 7 \\
\hline 1. & $\begin{array}{l}\text { Supervisory ethical } \\
\text { leadership (T1) }\end{array}$ & 3.85 & .59 & $(.87)$ & & & & & & \\
\hline 2. & $\begin{array}{l}\text { Cognitive } \\
\text { engagement (T2) }\end{array}$ & 4.04 & .58 & $.21 * *$ & (.69) & & & & & \\
\hline 3. & Voice (T2) & 3.92 & .56 & $.26^{* *}$ & $.45^{* *}$ & $(.82)$ & & & & \\
\hline 4. & Exit intentions (T2) & 3.11 & .79 & $-.23 * *$ & $-.25^{*}$ & $-.26 * *$ & $(.83)$ & & & \\
\hline 5. & Silence (T1) & 3.11 & .68 & .03 & -.03 & $-.11^{+}$ & -.10 & $(.74)$ & & \\
\hline 6. & Exit intentions (T1) & 3.07 & .77 & $-.26^{* *}$ & $-.17 * *$ & $-.17 *$ & $.48 * *$ & -.08 & $(.87)$ & \\
\hline 7. & Employability (T2) & 3.66 & .70 & $-.15^{*}$ & -.03 & .10 & $.44 * *$ & $-.18 * *$ & $.19 * *$ & $(.85)$ \\
\hline
\end{tabular}

Note. $N=306$. Cronbach's alphas are reported on the diagonal in parentheses. ${ }^{+} p<.1 ; * p<.05 ; * * p<.01$. 
Table 2: Results of CFA

\begin{tabular}{lllllll}
\hline \hline & $\chi^{2}$ & d.f. & $\Delta \boldsymbol{\chi}^{2}$ & CFI & IFI & RMSEA \\
\hline 7-Factor Model & 987.41 & 609 & - & .95 & .95 & .05 \\
1-Factor Model & 3308.59 & 629 & 2321.18 & .66 & .66 & .17 \\
2-Factor Model a $^{2}$ & 2798.07 & 628 & 1810.66 & .72 & .73 & .15 \\
3-Factor Model b $^{\text {b }}$ & 2412.75 & 626 & 1425.34 & .77 & .77 & .13 \\
\hline \hline
\end{tabular}

$\Delta \chi^{2}$ compared with 7-factor model.

${ }^{a}$ Factor 1 (T1 variables): supervisory ethical leadership, silence, and lag exit intentions; Factor 2 (T2 variables) cognitive engagement, voice, exit intentions, and employability.

${ }^{\mathrm{b}}$ Factor 1 (independent and control variables): supervisory ethical leadership, silence, lag exit intentions, and employability; Factor 2 (mediators): cognitive engagement, voice; Factor 3 (dependent variable): exit intentions.

$\mathrm{IFI}=.95 ; \mathrm{RMSEA}=.05)$ among all the measurement models. The improvement in overall fit is also statistically significant when we compare the seven-factor model with the one-factor model $\left(\Delta \chi^{2}=2321.18, \mathrm{p}<.001\right)$ and the two alternative models $\left(\Delta \chi^{2}=1810.66\right.$ and 1425.34 , respectively, $\left.\mathrm{p}<.001\right)$, suggesting that respondents can distinguish between the constructs.

Our hypothesized model (Model 1) also shows a good fit $\left(\chi^{2}=1066.01\right.$, d.f. $=647$; $\mathrm{CFI}=.95 ; \mathrm{IFI}=.95 ; \mathrm{RMSEA}=.05)$. To test our hypotheses on mediation, we further estimate an alternative model (Model 2). In this model, the direct path from ethical leadership to voice is significant $(\beta=.14, \mathrm{p}<.05)$, but the direct path from ethical leadership to exit is not $(\beta=-.02$, n s.). Compared with Model 1, Model 2 shows a similar fit $\left(\chi^{2}=1062.71\right.$, d.f. $=645 ; \mathrm{CFI}=.95$; IFI $\left.=.95 ; \mathrm{RMSEA}=.05\right)$, and the improvement is not statistically significant $\left(\Delta \chi^{2}=3.30, \Delta\right.$ d.f. $=2$, n.s. $)$. With these results, we run a revised Model 2 by removing the non-significant path (i.e., ethical leadership $\rightarrow$ exit intentions); the result shows that the revised Model 2 has a significant improvement in the overall fit compared with Model 1 $\left(\chi^{2}=1062.77\right.$, d.f. $=646 ; \mathrm{CFI}=0.95 ; \mathrm{IFI}=.95 ; \mathrm{RMSEA}=.05 ; \Delta \chi^{2}=3.24, \Delta$ d.f. $=1$; $\mathrm{p}<0.1)$. Therefore, we conclude that the revised Model 2 provides a better fit for our data (see Figure 1).

As Figure 1 shows, all the paths are statistically significant and in the hypothesized direction. Specifically, supervisory ethical leadership is positively related to cognitive engagement $(\beta=.26, \mathrm{p}<.01)$. Cognitive engagement is also positively related to voice $(\beta=.51, \mathrm{p}<.001)$, after we account for the direct effect of supervisory ethical leadership on voice $(\beta=.15, \mathrm{p}<.05)$. More important, the Sobel test shows a significant indirect effect of supervisory ethical leadership on voice through cognitive engagement (indirect effect $=.13, \mathrm{p}<.01$ ). These results provide support for $\mathrm{H} 1$.

$\mathrm{H} 2$ states that employee exit intentions are related to employee voice. After we control for exit at T1, employability at T2, and a dummy variable of plant site, the path from voice to exit remains statistically significant $(\beta=-.29, p<.001)$. Thus, $\mathrm{H} 2$ is supported. Finally, $\mathrm{H} 3$ states that cognitive engagement and employee voice mediate the relationship between ethical leadership and employee exit intentions. As Figure 1 depicts, all the hypothesized paths connecting ethical leadership and exit intentions through cognitive engagement and voice are statistically significant. Based on the Sobel test approach, LISREL estimates the overall indirect effect of 
ethical leadership on exit intentions according to these paths. The overall indirect effect is significant (indirect effect $=-.08, \mathrm{p}<.01$ ), in support of $\mathrm{H} 3$.

\section{SUPPLEMENTARY STUDY}

In the previous analyses, we collected employees' evaluations of supervisory ethical leadership in the manufacturing context and operationalized supervisory ethical leadership as an individual-level construct. While other studies have used the same approach (e.g., Piccolo et al., 2010), it is important to note that ethical leadership is originally conceptualized as a group-level construct (Brown et al., 2005; Schaubroeck Hannah, Avolio, Kozlowski, Lord, Treviño, Dimotakis, \& Peng, 2012). As such, a study context of multiple groups will be more ideal to operationalize ethical leadership so that researchers can evaluate if members of the same group share consensus regarding ethical leadership behaviors of their supervisors (Chan, 1998). For these reasons, we conducted a supplementary study based on groups of hospital nurses and measured supervisory ethical leadership as a group-level construct. One of our study's objectives is to use different samples to replicate established results of prior studies regarding the relationship between ethical leadership and voice. We thus chose a non-manufacturing context (i.e. hospital nurses) in conducting our supplementary study, in which we also analyze whether voice can account for the relationship between supervisory ethical leadership and exit intentions.

\section{Sample and Procedures}

We conducted this supplementary study, which involved nurses from 29 work groups, at a hospital in Wuhan, a city located in central China. During survey administration, the nurses were told that their participation was voluntary and the information they provided would be kept confidential.

At Time-1, we distributed questionnaires to 345 nurses. All the nurses provided information on their education, age, organizational tenure, and supervisors' ethical leadership behavior. Three hundred thirty-one nurses returned usable questionnaires, representing a response rate of $95.9 \%$. At Time-2, two months after Time- 1 , we asked the nurses to fill out questionnaires about voice and intention to quit. In this round of the survey, 315 of the 345 nurses returned usable questionnaires, for a response rate of $91.3 \%$. All the respondents in the sample are women. Nurses on average are 30.75 years of age, and their average organizational tenure is 9.75 years.

\section{Measures}

Similar to what we did in the first study, we conducted back translation (Brislin, 1970) to ensure there were no semantic differences between the original English measurement and the translated Chinese version. The respondents rated the items on the following measures on a 5 -point Likert scale ( 1 = "strongly disagree"; $5=$ "strongly agree").

Supervisory ethical leadership (T1). We used the same ethical leadership scale developed by Brown et al. (2005). The coefficient alpha is .95 . Because our focus is on supervisory ethical leadership behavior displayed in the work group as a whole, 
we aggregated the nurses' individual ratings of their supervisors' ethical leadership behavior within groups. We calculated within-group agreement $\left(\mathrm{r}_{\mathrm{wg}}\right)$, the intra-class correlations $\left(\mathrm{ICC}_{[1]}\right)$, and the reliability of the means $\left(\mathrm{ICC}_{[2]}\right)$ to assess whether it is appropriate to aggregate individual ratings to the work-group level. Given the satisfactory results (i.e., $\mathrm{r}_{\mathrm{wg}}=.94 ; \mathrm{ICC}_{[1]}=.10, p<.01 ; \mathrm{ICC}_{[2]}=.77$ ), we aggregated the individual-level ratings of ethical leadership to the work-group level.

Voice (T2). We used the same scale developed by Van Dyne and LePine (1998) to measure voice among nurses. Cronbach's alpha was .85 .

Exit intentions (T2). We also used the same scale developed by Rosin and Korabik (1991) to measure exit intention. This scale has a Cronbach's alpha of .85.

Control variables. We controlled for nurses' organizational tenure because they may affect employees' voice (Tangirala \& Ramanujam 2008). We also controlled for education because more educated employees may have more ideas to make suggestions and voice (Liang, Farh, \& Farh, 2012).

\section{Analytical Strategy}

We used hierarchical linear modeling (HLM; Bryk \& Raudenbush, 1992) because it can address analytical problems stemming from the potential interdependence of responses from individuals within the same group (Hofmann, 1997). Given the significant between-group differences in nurses' voice $\left(\mathrm{ICC}_{[1]}=.13, \mathrm{p}<.001\right)$ and exit $\left(\mathrm{ICC}_{[1]}=.05, \mathrm{p}<.05\right)$, we followed Hofmann's (1997) suggestion and conducted random coefficient regression models to test the relationships among supervisory ethical leadership, voice, and exit intentions.

\section{Results}

Table 3 shows the means, standard deviations, and correlations among all the variables. Because nurses provided information about supervisory ethical leadership, voice, and exit intentions, we conducted CFA to examine whether they could distinguish the three constructs. The CFA results show that the constructs in this study are distinct. The three-factor model offers better fit $\left(\chi^{2}=447.38\right.$, d.f. $=167$; $\mathrm{CFI}=.97$; IFI $=.97$; RMSEA $=.043)$ than the one-factor model $\left(\Delta \chi^{2}=2238.53\right.$, $\mathrm{p}<.001$, d.f. $=170, \mathrm{CFI}=.83 ; \mathrm{IFI}=.83 ; \mathrm{RMSEA}=.17$ ).

Table 3: Means, Standard Deviations, Reliabilities, and Inter-Correlations of the Supplementary Study's Variables

\begin{tabular}{lllrrrrrr}
\hline \hline & Variables & Mean & \multicolumn{1}{c}{ SD } & 1 & $\mathbf{2}$ & $\mathbf{3}$ & $\mathbf{4}$ & $\mathbf{5}$ \\
\hline 1 & Ethical leadership (T1) & 3.62 & .70 & $(.95)$ & & & & \\
2 & Voice (T2) & 3.51 & .54 & $.20^{* * * *}$ & $(.85)$ & & & \\
3 & Exit (T2) & 1.94 & .99 & $-.20^{* * *}$ & $-.24^{* * *}$ & $(.85)$ & & \\
4 & Organizational tenure (T1) & 9.75 & 11.06 & -.01 & $.13^{*}$ & $-.35^{* * *}$ & - \\
5 & Education (T1) & 3.25 & 2.02 & -.04 & -.06 & -.08 & $-.16^{* *}$ & - \\
\hline \hline
\end{tabular}

Note. $N=315$. Cronbach's alphas are reported on the diagonal in parentheses. ${ }^{+} p<.1 ; * p<.05 ; * * p<.01$. 
Table 4 shows the HLM results of hypotheses testing. Consistent with what we found in the previous study, Model 2 reveals that the group-level measure of supervisory ethical leadership is positively related to nurses' voice $(\gamma=.43, \mathrm{p}<.01)$.

As Model 4 shows, supervisory ethical leadership is negatively related to nurses' exit intentions $(\gamma=-.56, \mathrm{p}<.001)$. According to Baron and Kenny (1986), we thus have some evidence of mediation as supervisory ethical leadership is positively related to both the mediator (i.e., voice) and the outcome (i.e., exit intentions). To further assess whether supervisory ethical leadership has an indirect effect on exit intentions through voice, we followed Baron and Kenny's (1986) suggestion to run another model by regressing exit intentions on both supervisory ethical leadership and voice. The results of Model 5 show that the effect of supervisory ethical leadership on exit intentions becomes weaker $(\gamma=-.46, \mathrm{p}<.01)$ when voice is included in the same regression equation $(\gamma=-.36, \mathrm{p}<.01)$. This finding evidences voice as a mediator, according to Baron and Kenny (1986). A Sobel test shows that the indirect effect of supervisory ethical leadership on exit intentions through voice $(.43 \times-.36=-.15)$ is statistically significant $(\mathrm{Z}=2.24, \mathrm{p}<.05)$.

\section{DISCUSSION}

In this study, we argue that supervisory ethical leadership increases employee voice and reduces employee exit intentions. Using a sample of 306 manufacturing employees, we find that supervisory ethical leadership measured at T1 has a significant relationship to cognitive job engagement measured at T2. Our analyses also show that, after controlling for the proxies of voice and exit intention at T1, cognitive job engagement mediates the positive effect of supervisory ethical leadership on employee voice at T2 and, subsequently, the indirect effect of supervisory ethical

Table 4: HLM Results of Supervisory Ethical Leadership and Voice on Exit Intentions

\begin{tabular}{|c|c|c|c|c|c|}
\hline & \multicolumn{3}{|c|}{ Voice } & \multicolumn{2}{|l|}{ Exit } \\
\hline & Model 1 & Model 2 & Model 3 & Model 4 & Model 5 \\
\hline \multicolumn{6}{|l|}{ Control variables } \\
\hline Intercept & $3.52 * * *(.04)$ & $3.51 * * *(.04)$ & $1.96 * * *(.06)$ & $1.98 * * *(.05)$ & $2.00 * * *(.05)$ \\
\hline $\begin{array}{l}\text { Organizational } \\
\text { tenure }\end{array}$ & $.01 *(.004)$ & $.01 *(.005)$ & $-.03^{* * *}(.005)$ & $-.03 * * *(.005)$ & $-.03 * * *(.005)$ \\
\hline Education & $.07(.06)$ & $.09(.07)$ & $.14(.08)$ & $.13(.08)$ & $.18 *(.08)$ \\
\hline \multicolumn{6}{|c|}{ Independent variable } \\
\hline $\begin{array}{l}\text { Supervisory } \\
\text { Ethical } \\
\text { leadership }\end{array}$ & & $.43 * *(.14)$ & & $-.56^{* * *}(.14)$ & $-.46^{* *}(.13)$ \\
\hline \multicolumn{6}{|l|}{ Mediator } \\
\hline Voice & & & & & $-.36 * *(.11)$ \\
\hline $\mathrm{R}^{2}$ (within) & .11 & - & .10 & - & .17 \\
\hline $\mathrm{R}^{2}$ (between) & - & .52 & - & .62 & - \\
\hline
\end{tabular}

Note. $* p<.05 ; * * p<.01$. 
leadership on exit intentions at T2. In a supplementary study, we replicate the association of supervisory ethical leadership (measured at the group level) with voice in a sample of 315 nurses in 29 work groups. We also find that ethical leadership is indirectly related to exit intentions through voice.

Our study contributes to research on ethical leadership (Brown et al., 2005) and voice (Morrison et al., 2011) in several ways. First, although ethical leadership theory posits motivation as a possible mechanism of how ethical leaders influence followers, limited evidence exists on the motivational aspect of ethical leadership (e.g., Den Hartog \& Belschak, 2012). Because ethical leaders use moral values to motivate followers, their motivational influence is important for understanding ethical leadership (Shamir et al., 1993). Using Kahn's (1990) theory of work engagement, we demonstrated why followers may be more willing to focus their energies during the performance of their work roles. Our study provides empirical evidence that the motivational state of cognitive engagement can enhance our understanding of the ethical leaders' influence on employees.

Second, employee voice is beneficial because organizations need employees' ideas to remain creative and employees' feedback for continuous improvement (Burris, 2012; Morrison \& Milliken, 2000; Van Dyne, Ang, \& Botero, 2003; Zhou \& George, 2001). Thus, to understand why employees voice, Ashford, Sutcliffe, and Christianson (2009: 181) have called for more studies on the influence of leadership, as the contribution "leadership might make to the psychology of voice is complex and relatively unexplored". By demonstrating the indirect effect of supervisory ethical leadership on voice through cognitive engagement in two samples in China, our study also sheds light on the psychological processes by which ethical leadership helps develop employees' idea generation and encourages them to speak up.

Third, Thomas et al. (2004) argue that ethical leadership is important for organizations because it has potential to lower employees' intentions to leave organizations. Our analyses show that by encouraging employee voice, supervisory ethical leadership can also decrease employees' exit intentions. Although voice and exit have been conceived as two distinct outcomes of employee dissatisfaction (Rusbult et al., 1988; Withey \& Cooper, 1989), our study shows that supervisory ethical leadership can account for these two employee responses simultaneously by assuring employees that they can influence organizations through voice and, subsequently, by increasing their intentions to stay with organizations.

Our study also has several practical implications. Through supervisory ethical leadership, organizations can benefit from employees who are willing to offer suggestions and exhibit little turnover intention. As such, organizations should encourage leaders to uphold their moral standards when managing subordinates in order to foster supervisory ethical leadership. As this type of leadership requires transactional means to hold employees ethically accountable for their behavior, organizations should also implement performance appraisal and reward systems that are consistent with ethical leaders' emphasis on moral standards. Our study also reveals that cognitive engagement accounts for the effect of supervisory ethical leadership on employees' voice, which further lowers their exit intentions. According to Kahn (1990), employees are more willing to be cognitively engaged under ethical leaders because of work meaningfulness, psychological safety, and self-efficacy. As such, supervisors may consider emphasizing 
the importance of adhering to ethical standards among their subordinates, their willingness to listen, and their readiness to offer help and guidance to subordinates. Doing so will further enhance subordinates' cognitive engagement in performing their work.

Although our study offers several contributions, it also has several limitations. First, we used the commonly adopted scale to measure supervisory ethical leadership (i.e., Brown et al., 2005) but such data capture employee perceptions rather than actual leadership behaviors. Thus, we encourage research to examine actual supervisory behaviors consistent with what executives deem ethical in assessing the impact of ethical leadership on employee voice (Treviño et al., 2003). Moreover, employee voice and exit intentions are self-reported, and thus our measures capture only intentions, not actual behavior. We therefore cannot rule out the possibility that ethical leadership influences only intentions, not actual behavior. Future studies should consider soliciting peers or supervisors to report on actual employee voice behavior and turnover. Second, because employees provided data on both the independent and dependent variables, we cannot completely rule out the problem of common method variance, though the CFA results show that employees can discriminate between the constructs. Our control of the time-lagged measures of silence and exit intentions when evaluating our hypotheses should further reduce concerns about common method variance. Third, our data are from manufacturing workers in mainland China and Macau, where there is a high power distance and employee voice is discouraged. Our findings show that the current understanding of leadership and voice developed in the West remains applicable in such a cultural context (Lam et al., 2012). However, readers should still exercise caution in generalizing our findings beyond this sample. Due to these limitations, we conducted a supplementary study by measuring ethical leadership at the group (as opposed to individual) level and collecting data in a non-manufacturing context (i.e., hospital nurses). Future studies however could consider replicating our results using more objective measures of voice and exit in other non-manufacturing and professional contexts.

Several other promising research areas could shed light on ethical leaders' influence on employees. One area is the job context of followers under ethical leadership. Brown et al. (2005) argue that the guidance of ethical leaders is more pronounced for ill-defined jobs, for which standard operating procedures are less available. As such, employees under these job contexts might find the support and guidance of ethical leaders more useful, such that they will be more confident in engaging their selves when performing their jobs. The authors further suggest that compared with employees working in the technical core of organizations, those who work as boundary spanners may face role conflicts more often. In this case, ethical leadership can provide the assurance for them to cognitively focus on their work and not to be distracted by such conflicts.

Another area of future study involves managerial responses to employee voice. Burris (2012) finds that managers view employees as loyal if their voice is supportive but as threatening if their voice is challenging. These perceptions also determine whether managers will endorse employees' ideas. We posit that ethical leaders are more receptive to employees' voice, so ethical leadership may also moderate the relationship between voice and managerial endorsement. 
Ethical leaders have high moral standards and explicitly communicate to followers their standards and expectations of appropriate and inappropriate conduct (Treviño et al., 2003). Thus, they are likely to welcome and encourage employees' voice as a means to improve workplace conditions (Brown et al., 2005; Detert \& Edmonson, 2011; Toor \& Ofori, 2009; Walumbwa \& Schaubroeck, 2009). In addition to voice, Mayer et al. (2012) find that departments report less unethical behavior when they are led by ethical leaders. As such, it will be useful to explore how ethical leaders are able to do so. We posit employees' moral reasoning to be a possible mechanism because employees with such ability may be less likely to be morally disengaged and are able to respond to work demands more ethically (Treviño, 1992; Brown \& Mitchell, 2010). Using Kohlberg's (1981) approach to individual levels of moral reasoning, research could analyze whether moral reasoning accounts for the relationship between ethical leadership and employees' ethical behavior.

In conclusion, our study shows that ethical leaders can influence employees through the motivational state of cognitive engagement. Such motivational influence can account for why employees are more willing to use voice and less likely to exit under ethical leaders. Thus, our study advances the current understanding of ethical leaders' influence on employees.

\section{ACKNOWLEDGEMENTS}

This paper was partially supported by a direct grant from the University of Macau (Research Grant RG010/09-10S/LCH/FBA) to the first, second and third authors. Correspondence concerning this article can be addressed to Yan Liu, Department of Business Administration, Wuhan University leannaliu@whu.edu.cn.

\section{REFERENCES}

Arkes, H. R., \& Blumer, C. 1985. The psychology of sunk cost. Organizational Behavior and Human Decision Processes, 35: 124-40.

Ashford, S. J., Sutcliffe, K., \& Christianson, M. 2009. Speaking up and speaking out: The leadership dynamics of voice in organizations. In Greenberg, J. \& Edwards, M. S. (Eds.), Voice and silence in organizations: 175-202. Bingley, UK: Emerald Group.

Avey, J. B., Wernsing, T. S., \& Palanski, M. E. 2012. Exploring the process of ethical leadership: The mediating role of employee voice and psychological ownership. Journal of Business Ethics, 107: 21-34.

Bandura, A. 1986. Social foundations of thought and action: A social cognitive theory. Englewood Cliffs, NJ: Prentice Hall.

Baron, R. M., \& Kenny, D. A. 1986. The moderator-mediator variable distinction in social psychological research: Conceptual, strategic, and statistical considerations. Journal of Personality and Social Psychology, 51: 1173-82.

Bashshur, M. R., \& Oc, B. 2015. When voice matters: A multi-level review of the impact of voice in organizations. Journal of Management, 41: 1530-54.

Bentler, P. M., \& Bonett, D. G. 1980. Significance tests and goodness of fit in the analysis of covariance structures. Psychological Bulletin, 88: 588-606.

Boroff, K. E., \& Lewin, D. 1997. Loyalty, voice, and intent to exit a union firm: A conceptual and empirical analysis. Industrial and Labor Relations Review, 51: 50-63. 
Brislin, R. W. 1970. Back-translation for cross-cultural research. Journal of Cross-Cultural Psychology, 1: 185-216.

Brockner, J., Ackerman, G., Greenberg, J., Gelfand, M. J., Francesco, A. M., Chen, Z. X., Leung, K., Bierbrauer, G., Gomez, C., Kirkman, B. L., \& Shapiro, D. 2001. Culture and procedural justice: The influence of power distance on reaction to voice. Journal of Experimental Social Psychology, 37: 300-315.

Brown, M. E. 2007. Misconceptions of ethical leadership: How to avoid potential pitfalls. Organizational Dynamics, 36: 140-55.

Brown, M. E., \& Mitchell, M. S. 2010. Ethical and unethical leadership: Exploring new avenues for future research. Business Ethics Quarterly, 20: 583-616.

Brown, M. E., \& Treviño, L. K. 2006. Ethical leadership: A review and future directions. Leadership Quarterly, 17: 595-616.

Brown, M. E., Treviño, L. K., \& Harrison, D. A. 2005. Ethical leadership: A social learning perspective for construct development and testing. Organizational Behavior and Human Decision Processes, 97: 117-34.

Brown, M. W., \& Cudeck, R. 1993. Alternative ways of assessing model fit. In Bollen, K. A. \& Long, J. S. (Eds.), Testing structural equation models: 136-62. Newsbury Park, CA: Sage.

Bryk, A. S., \& Raudenbush, S. W. 1992. Hierarchical linear models. Newbury Park, CA: Sage Publications.

Bryne, B. M. 1989. A primer of LISREL: Basic applications and programming for confirmatory factor analytic models. New York: Springer-Verlag.

Burris, E. R. 2012. The risks and rewards of speaking up: Managerial responses to employee voice. Academy of Management Journal, 55: 851-75.

Chan, D. 1998. Functional relations among constructs in the same content domain at different levels of analysis: A typology of composition models. Journal of Applied Psychology, 83: 234-246.

Crawford, E. R., LePine, J. A., \& Rich, B. L. 2010. Linking job demands and resources to employee engagement and burnout: A theoretical extension and meta-analytic test. Journal of Applied Psychology, 95: 834-848.

De Cuyper, N., Notelaers, G., \& De Witte, H. 2009. Job insecurity and employability in fixed-term contractors, agency workers, and permanent workers: Associations with job satisfaction and affective organizational commitment. Journal of Occupational Health Psychology, 14: 193-205.

Den Hartog, D. N. \& Belschak, F. D. 2012. Work engagement and Machiavellianism in the ethical leadership process. Journal of Business Ethics, 107: 35-47.

Detert, J. R., \& Edmondson, A. C. 2011. Implicit voice theories: Taken-for-granted rules of self-censorship at work. Academy of Management Journal, 54: 461-88.

Detert, J., Treviño, L. K., Burris, E., \& Andiappan, M. 2007. Managerial models of influence and counterproductivity in organizations: A longitudinal business unitlevel investigation. Journal of Applied Psychology, 92: 993-1005.

Eisenberger, R., Armeli, S., Rexwinkel, B., Lynch, P. D., \& Rhoades, L. 2001. Reciprocation of perceived organizational support. Journal of Applied Psychology, 86: 42-51.

Eisenberger, R. \& Stinglhamber, F. 2011. Perceived organizational support: Fostering enthusiastic and productive employees. Washington, DC: APA Books.

Ethics Research Centre. 2011. 2011 National Business Ethics Survey - Workplace Ethics in Transition. Arlington, VA: Ethics Research Centre.

Frazier, P. A., Tix, A. D., \& Barron, K. E. 2004. Testing moderator and mediator effects in counseling psychology research. Journal of Counseling Psychology, 51: 115-34. 
Fugate, M., Kinicki, A. J., \& Ashforth, B. E. 2004. Employability: A psycho-social construct, its dimensions, and applications. Journal of Vocational Behavior, 65: 14-38.

Gong, Y. P., Cheung, S. Y., Wang, M., \& Huang, J. C. 2012. Unfolding the proactive process for creativity: Integration of the employee proactivity, information exchange, and psychological safety perspectives. Journal of Management, 38: 1611-33.

Hirschman, A. O. 1970. Exit, voice, and loyalty: Responses to decline in firms, organizations, and states. Cambridge, MA: Harvard University Press.

Hochschild, A. 1983. The managed heart: Communication of human feeling. Berkeley, CA: University of California Press.

Hofmann, D. A. 1997. An overview of the logic and rationale of hierarchical linear models. Journal of Management, 23: 723-744.

Hu, L., \& Bentler, P. M. 1998. Fit indices in covariance structure modeling: Sensitivity to underparameterized model misspecification. Psychological Methods, 3: 424-53.

Huang, C. J. 2010. Corporate governance, corporate social responsibility and corporate performance. Journal of Management and Organization, 16: 641-55.

Kahn, W. A. 1990. Psychological conditions of personal engagement and disengagement at work. Academy of Management Journal, 33: 692-724.

Kanfer, R., \& Ackerman, P. L. 1989. Motivation and cognitive abilities: An integrative/ aptitude-treatment interaction approach to skill acquisition. Journal of Applied Psychology, 74: 657-90.

Kenny, D. A., Kashy, D. A., \& Bolger, N. 1998. Data analysis in social psychology. In Gilbert, D. T., Fiske, S. T., \& Lindzey, G. (Eds.), The handbook of social psychology (4 ${ }^{\text {th }}$ ed.): $233-65$. New York: Oxford University Press.

Kohlberg, L. 1981. The philosophy of moral development: Essays on moral development. San Francisco: Harper \& Row.

Lam, L. W., Huang, X., \& Lau, D. 2012. Leadership research in Asia: Taking the road less traveled? Asia Pacific Journal of Management, 29: 195-204.

Lee, T. W., \& Mitchell, T. R. 1994. An alternative approach: The unfolding model of voluntary employee turnover. Academy of Management Review, 19: 51-89.

Liang, J., Farh, C. I. C., \& Farh, J.-L. 2012. Psychological antecedents of promotive and prehibitive voice: A two-wave examination. Academy of Management Journal, 55: 71-92.

Lin, C.-P. 2010. Modeling corporate citizenship, organizational trust, and work engagement based on attachment theory. Journal of Business Ethics, 94: 517-31.

Lind, E. A., \& Tyler, T. R. 1988. The social psychology of procedural justice. New York: Plenum Press.

Loi, R., Lam, L. W., Ngo, H. Y., \& Cheong, S. 2015. Exchange mechanisms between ethical leadership and affective commitment. Journal of Managerial Psychology, 30: $645-658$.

Loi, R., Ngo, H. Y., \& Foley, S. 2006. Linking employees' justice perceptions to organizational commitment and intentions to leave: The mediating role of perceived organizational support. Journal of Occupational and Organizational Psychology, 79: 101-20.

MacKinnon, D. P., Lockwood, C. M., \& Williams, J. 2004. Confidence limits for the indirect effect: Distribution of the product and resampling methods. Multivariate Behavioral Research, 39: 99-128.

May, D. R., Gilson, R. L., \& Harter, L. M. 2004. The psychological conditions of meaningfulness, safety and availability and the engagement of the human spirit at work. Journal of Occupational and Organisational Psychology, 77: 11-37. 
Mayer, D. M., Aquino, K., Greenbaum, R. L., \& Kuenzi, M. 2012. Who displays ethical leadership and why does it matter? An examination of antecedents and consequences of ethical leadership. Academy of Management Journal, 55: 151-71.

Mayer, D. M., Kuenzi, M., Greenbaum, R., Bardes, M., \& Salvador, R. B. 2009. How low does ethical leadership flow? Test of a trickle-down model. Organizational Behavior and Human Decision Processes, 108: 1-13.

Mayer, R. C., \& Gavin, M. B. 2005. Trust in management and performance: Who minds the shop while the employees watch the Boss? Academy of Management Journal, 48: 874-88.

Mendonca, M., \& Kanungo, R. N. 2007. Ethical leadership. New York: McGraw-Hill.

Milliken, F. J., Morrison, E. W., \& Hewlin, P. F. 2003. An exploratory study of employee silence: Issues that employees don't communicate upward and why. Journal of Management Studies, 40: 1453-67.

Morrison, E. W., \& Milliken, F. J. 2000. Organizational silence: A barrier to change and development in a pluralistic world. Academy of Management Review, 25: 706-25.

Morrison, E. W., Wheeler-Smith, S. L., \& Kamdar, D. 2011. Speaking up in groups: A cross-level study of group voice climate and voice. Journal of Applied Psychology, 96: 183-91.

Neubert, M. J., Carlson, D. S., Kacmar, K. M., Roberts, J. A., \& Chonko, L. B. 2009. The virtuous influence of ethical leadership behavior: Evidence from the field. Journal of Business Ethics, 90: 157-70.

Olson-Buchanan, J. B., \& Boswell, W. R. 2002. The role of employee loyalty and formality in voicing discontent. Journal of Applied Psychology, 87: 1167-74.

Palanski, M., Avey, J. B., \& Jiraporn, N. 2014. The effects of ethical leadership and abusive supervision on job search behaviors in the turnover process. Journal of Business Ethics, 121: 135-46.

Piccolo, R. F., Greenbaum, R., Hartog, D. N. D., \& Folger, R. 2010. The relationship between ethical leadership and core job characteristics. Journal of Organizational Behavior, 31: 259-78.

Premeaux, S. F., \& Bedeian, A. G. 2003. Breaking the silence: The moderating effects of self-monitoring in predicting speaking up in the workplace. Journal of Management Studies, 40: 1537-62.

Rich, B. L., Lepine, J. A., \& Crawford, E. R. 2010. Job engagement: Antecedents and effects on job performance. Academy of Management Journal, 53: 517-635.

Rosin, H. M., \& Korabik, K. 1991. Workplace variables, affective responses, and intention to leave among women managers. Journal of Occupational Psychology, 64: 317-30.

Rothbard, N. P. 2001. Enriching or depleting? The dynamics of engagement in work and family roles. Administrative Science Quarterly, 46: 655-84.

Rusbult, C. E., Farrell, D., Rogers, G., \& Mainous, A. G., III. 1988. Impact of exchange variables on exit, voice, loyalty, and neglect: An integrative model of responses to declining job satisfaction. Academy of Management Journal, 31: 599-627.

Schaufeli, W. B., \& Bakker, A. B. 2004. Job demands, job resources, and their relationship with burnout and engagement: A multi-sample study. Journal of Organizational Behavior, 25: 293-315.

Schaubroeck, J. M., Hannah, S. T., Avolio, B. J., Kozlowski, S. W., Lord, R. G., Treviño, L. K., Dimotakis, N., \& Peng, A. C. 2012. Embedding ethical leadership within and across organizational levels. Academy Of Management Journal, 55: 1053-1078. 
Schneider, B., Ehrhart, M. G., Mayer, D. M., Saltz, J. L., \& Niles-Jolly, K. 2005. Understanding organization-customer links in service settings. Academy of Management Journal, 48: 1017-32.

Shamir, B., House, R., \& Arthur, M. B. 1993. The motivational effects of charismatic leadership: A self-concept based theory. Organizational Science, 4: 577-91.

Shrout, P. E., \& Bolger, N. 2002. Mediation in experimental and non-experimental studies: New procedures and recommendations. Psychological Methods, 7: 422-45.

Spencer, D. G. 1986. Employee voice and employee retention. Academy of Management Journal, 29: 488-502.

Tangirala, S., \& Ramanujam, R. 2008. Exploring nonlinearity in employee voice: The effects of personal control and organizational identification. Academy of Management Journal, 51: 1189-1203.

Taylor, S. G. \& Pattie, M. W. 2014. When does ethical leadership affect workplace incivility? The moderating role of follower personality. Business Ethics Quarterly, 24: 595-616.

Thomas, T., Schermerhorn, J. R., Jr., \& Dienhart, J. W. 2004. Strategic leadership of ethical behavior in business. Academy of Management Executive, 18: 56-66.

Toor, S.-ur-R., \& Ofori, G. 2009. Ethical leadership: Examining the relationships with full range leadership model, employee outcomes, and organizational culture. Journal of Business Ethics, 90: 533-47.

Treviño, L. K. 1992. Moral reasoning and business ethics: Implications for research, education, and management. Journal of Business Ethics, 11: 445-59.

Treviño, L. K. \& Brown, M., 2014. Ethical leadership. In Day, D. V. (Ed.), The Oxford handbook of leadership and organizations: 524-39. New York: Oxford University Press.

Treviño, L. K., Brown, M., \& Hartman, L. P. 2003. A qualitative investigation of perceived executive ethical leadership: Perceptions from inside and outside the executive suite. Human Relations, 56: 5-37.

Treviño, L. K., Butterfield, K. B., \& McCabe, D. L. 1998. The ethical context in organizations: Influences on employee attitudes and behaviors. Business Ethics Quarterly, 8: 447-76.

Van Dyne, L., Ang, S., \& Botero, I. C. 2003. Conceptualizing employee silence and employee voice as multidimensional constructs. Journal of Management Studies, 40: 1359-92.

Van Dyne, L., \& LePine, J. A. 1998. Helping and voice extra-role behavior: Evidence of construct and predictive validity. Academy of Management Journal, 41: 108-19.

Walumbwa, F. O., Mayer, D. M., Wang, P., Wang, H., Workman, K., \& Christensen, A. L. 2011. Linking ethical leadership to employee performance: The roles of leadermember exchange, self-efficacy, and organizational identification. Organizational Behavior and Human Decision Processes, 115: 204-13.

Walumbwa, F. O., Morrison, E. W., \& Christensen, A. L. 2012. Ethical leadership and group in-role performance: The mediating roles of group conscientiousness and group voice. Leadership Quarterly, 23: 953-64.

Walumbwa, F. O., \& Schaubroeck, J. 2009. Leader personality traits and employee voice behavior: Mediating roles of ethical leadership and work group psychological safety. Journal of Applied Psychology, 94: 1275-86.

Weick, K. E., \& Roberts, K. H. 1993. Collective mind in organizations: Heedful interrelating on flight decks. Administrative Science Quarterly, 38: 357-81.

Withey, M. J., \& Cooper, W. H. 1989. Predicting exit, voice, loyalty, and neglect. Administrative Science Quarterly, 34: 521-39.

Zhou, J., \& George, J. M. 2001. When job dissatisfaction leads to creativity: Encouraging the expression of voice. Academy of Management Journal, 44: 682-96. 


\section{APPENDIX I. SCALE ITEMS}

\section{Supervisory Ethical Leadership}

My supervisor

1. Listens to what employees have to say.

2. Disciplines employees who violate ethical standards.

3. Conducts personal life in an ethical manner.

4. Has the best interests of employees in mind.

5. Makes fair and balanced decisions.

6. Can be trusted.

7. Discusses business ethics or values with employees.

8. Sets an example of how to do things the right way in terms of ethics.

9. Defines success not just by results but also the way that they are obtained.

10. When making decisions, asks what is the right thing to do.

\section{Cognitive Engagement}

1. Performing my job is so absorbing that I forget about everything else.

2. I often think about other things when performing my job. (reverse)

3. I am rarely distracted when performing my job.

4. Time passes quickly when I perform my job.

\section{$\underline{\text { Voice }}$}

1. I develop and make recommendations concerning issues that affect this work group.

2. I speak up and encourage others in this department to get involved in issues that affect the group.

3. I communicate my opinions about work issues to supervisor or others in this dept.

4. I keep well informed about issues where my opinion might be useful to this work unit.

5. I get involved in issues that affect the quality of work life here in this group.

6. I speak up with ideas for new projects or changes in procedures.

\section{Exit Intentions}

1. At this time I would quit my job if it were feasible.

2. I am planning to leave my job within the next six months.

3. I am actively searching for another job right now.

4. I have thoughts about leaving this organization.

\section{Silence}

1. I chose to remain silent when I had concerns about my work.

2. Although I had ideas for improving my work, I did not speak up.

3. I said nothing to others about problems I noticed in my workplace.

4. I remained silent when I had information that might have helped prevent an incident in my workplace. 
5. I kept quiet instead of asking questions when I wanted to get more information about my work.

\section{Employability}

1. I can easily find another job elsewhere instead of my present job.

2. I am confident that I could quickly gain another job with another employer.

3. I could easily switch to another employer, if I wanted to.

4. I have a good chance of getting a job elsewhere, if I looked for one. 